\title{
Clinical Reasoning: A 14-year-old girl with headache, seizures, and confusion
}

Lijun Xiao, MD, Wenping Gu, MD, PhD, Bin Jiao, MD, PhD, Yunhai Liu, MD, PhD, and Xiaosu Yang, MD, PhD

Neurology ${ }^{\circledR}$ 2019;92:e161-e167. doi:10.1212/WNL.0000000000006726

\author{
Correspondence \\ Dr. Gu \\ Guwenping393@sohu.com
}

\section{Section 1}

A 14-year-old girl without any relevant medical history was transferred to our institution due to worsening headache along with nausea, vomiting, and generalized tonic-clonic (GTC) seizures for 7 days. She was also noted to have multiple psychological and behavioral abnormalities for 1 day. Her headache was described as severe holocephalic pain aggravated when lying down and alleviated after vomiting. No throbbing or phonophobia/photophobia was observed. Her seizures occurred once or twice a day, lasting about 1 minute each and resolving spontaneously. Symptoms were refractory to rotundine (dopamine D1 receptor antagonist), azasetron (antiemetic), mannitol, oxcarbazepine, and phenobarbital.

Psychological and behavioral abnormalities were noted including singing, raving, crying, and laughing intermittently. On physical examination, exotropia, hyperpigmentation of the skin, and long fingers were observed. On neurologic examination, the patient was unable to follow commands but responded to noxious stimuli. Funduscopic examination revealed papilledema. Plantar responses were extensor bilaterally.

D-dimer was high $(2.72 \mathrm{mg} / \mathrm{L}$, normal $<0.5 \mathrm{mg} / \mathrm{L})$, which suggested hypercoagulation and thrombogenesis. CT of head and intracranial arteries showed cerebral infarction and subarachnoid hemorrhage (figure 1, A) without arterial aneurysm or vascular malformation. Lumbar puncture revealed an opening pressure that was elevated at $300 \mathrm{~mm}$ of water, elevated red blood cells $\left(>1,000\right.$ cells $/ \mathrm{mm}^{3}$ ), and elevated white blood cells (about 20 cells $/ \mathrm{mm}^{3}$ ). CSF glucose, chloride, and protein were normal.

A continuous EEG showed diffuse background slowing with epileptiform discharges including frequent spikes and sharp waves present over the bilateral frontal and temporal regions. CT venography (CTV) revealed cerebral venous sinus thrombosis (CVST) with filling defects of the sigmoid and right lateral sinuses (figure 1, B). There was no family history of headache, epilepsy, or CVST.

\section{Question for consideration:}

1. What is the cause of the patient's CVST?

GO TO SECTION 2 

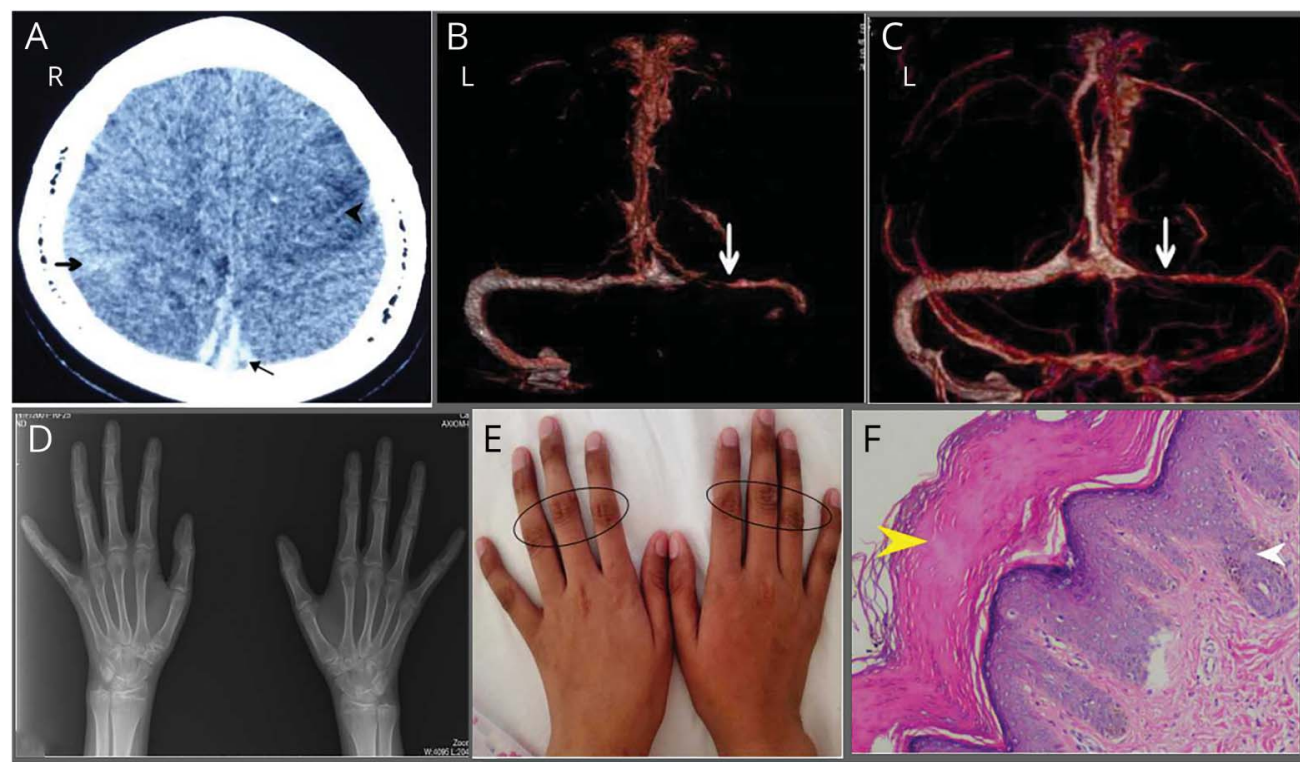

G
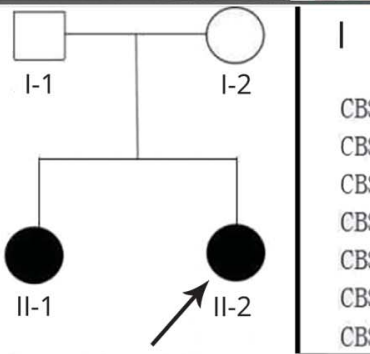

I

\begin{abstract}
p. Leu 184 Pro
\end{abstract}
$\checkmark$

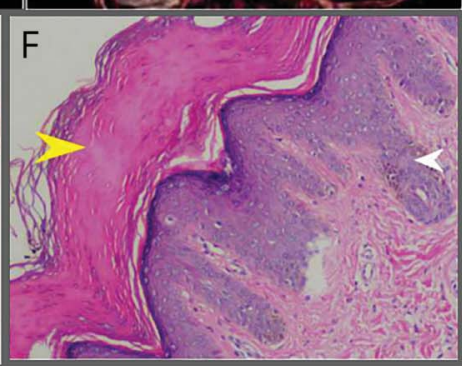

CBS HS KMSSEKVDV RALGAEIVRTPTNA---EGIGYDFIPTVLD TVVDKWFK CBS OC KMSLEKVDV RALGAEIVRTPTNA---EGIGYDFIPTVLD TVVDRWFK CBS RN KMSMEKVDV RALGAEIVRTPTNA---EGIGYDFIPTVLD AVVDRWFK CBS MM KMSUEKVDV RALGAEIVRTPTNA---EGIGYDFIPTVLD AVVDKWFK CBS DD KMSQEKVDV KALGGEIIRTPTEA---EGIGYDFIPNVLERKLVDQWIK CBS SC KMSNEKVSV KALGAEIIRTPTAA---EGIGYDFVPQVLD KLIDVWYK CBS TC KMSHEKEVTLQALGAEVIRTETAL---EGIGYDFVPDVCERKYVDRWVK

C T G C G G G CA C T G G G G G C T G A G
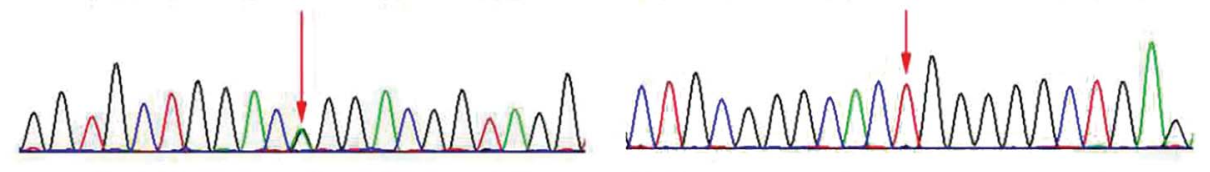

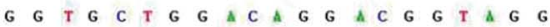

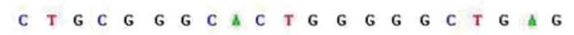

$1-2$
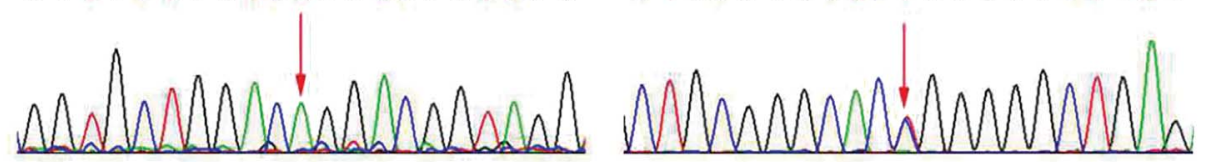

G $\quad$ G

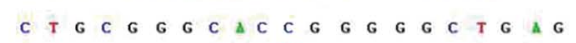

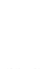
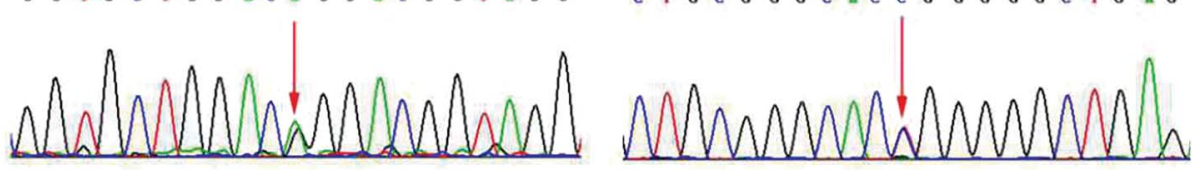

G $\quad$ G

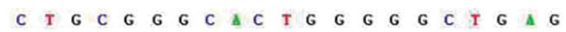

II-2

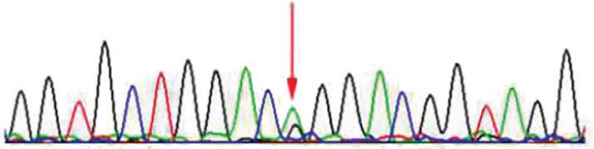

c.949AA/AG

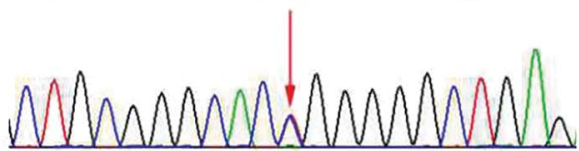

c.551TT/TC

(A) Brain CT shows cerebral infarction (triangle), subarachnoid hemorrhage (bold arrow), and thrombus of superior sagittal sinus (thin arrow). (B) CT venography (CTV) reveals cerebral venous sinus thrombosis (CVST) with filling defect of the right sigmoid sinus and right lateral sinuses (white arrow). (C) CTV after a month of treatment; the right sigmoid sinus and right lateral sinuses unobstructed but narrowed (white arrow). (D) X-ray suggests that joint space of bilateral wrist was narrowed. (E) The patient's long fingers. The circles show hyperpigmentation of skin, especially in the interphalangeal joints. (F) Histopathologic study of the patient's slightly darker skin reveals hyperkeratosis (yellow arrowhead) and verrucous hyperplasia in the basal layer of the epidermis (white arrowhead) (magnified $10 \times 10$ times under the microscope). (G) Pedigree of the family with homocystinuria. (H) Gene direct sequencing identified 2 novel compound heterozygous mutations: c.551T>C (p.L184P) and c.949A>G (p.R317G) (indicated by the red arrow). I-1: Heterozygous mutations of c.949A >G, the c.551 TT is normal; I-2: heterozygous mutations of c.551T>C, the c.949AA is normal; II-1, II-2: compound heterozygous mutations of c.551T>C and c.949A $>$ G. (I) Orthologous protein sequence alignment of cystathionine $\beta$-synthase from different species. The mutated residue showing conservation is shaded in red. Red shaded amino acids proteins show that the 2 novel missense mutations occurred at highly conserved positions in these species. DD = Dictyostelium discodeum; HS = Homo sapiens; MM = Mus musculus; OC = Oryctolagus cuniculus; RN = Rattus norvegicus, splice isoform III; SC = Saccharomyces cerevisiae; TC = Trypanosoma cruzi. 


\section{Section 2}

The primary cause for CVST is usually hypercoagulability due to acquired and genetic risks (table 1 ). ${ }^{1}$ The patient had no evidence of common risks in table 1 such as infection, vitamin deficiency, abnormal protein $\mathrm{C}$ or protein $\mathrm{S}$, estrogen-related factors, or others. However, she did have high level of plasma total homocysteine (Hcy) $(149.40 \mu \mathrm{mol} / \mathrm{L}$, normal $<15 \mu \mathrm{mol} / \mathrm{L})$.
Hcy causes approximately $4.5 \%$ of cases of CVST. ${ }^{2}$ It is a nonessential but indispensable sulfur-containing amino acid in humans. Hcy levels in the bloodstream can rise in 3 different ways $^{3}:$ (1) protein structure modifications; (2) oxidative stress induction; and (3) excitotoxicity. Hyperhomocysteinemia (HHcy) can lead to CVST and thromboembolism ${ }^{4}$ by causing prothrombotic conditions, endothelial dysfunction, and impaired thrombolysis. HHcy can also result in multisystem damage $^{5}$ (table 2) by the 3 main pathways mentioned above. ${ }^{3}$

Table 1 Causes of cerebral venous sinus thrombosis

\begin{tabular}{|c|c|}
\hline Acquired risks & Genetic risks \\
\hline Connective tissue disease & The prothrombin G20210A mutation \\
\hline Hematologic system diseases & Factor $\mathrm{V}$ Leiden gene mutations \\
\hline Infections & Protein C, protein S, and antithrombin III deficiencies \\
\hline Cancer & Genes associated with homocysteine metabolism \\
\hline Pregnancy and puerperium & Others \\
\hline Surgery, trauma, and other mechanical precipitants & Unidentified \\
\hline \multicolumn{2}{|l|}{ Exogenous hormones } \\
\hline \multicolumn{2}{|l|}{ Drug-associated conditions } \\
\hline Acquired HHcy & \\
\hline
\end{tabular}

Abbreviation: HHcy = hyperhomocysteinemia.

Table 2 Multiple target organs or systems damage caused by hyperhomocysteinemia reported in the literature and the 2 patients

\begin{tabular}{|c|c|c|c|}
\hline $\begin{array}{l}\text { Target } \\
\text { organs/ } \\
\text { systems }\end{array}$ & $\begin{array}{l}\text { Clinical characteristics reported } \\
\text { in the literature }\end{array}$ & II-1 (older sister) & II-2 (proband) \\
\hline Eye & $\begin{array}{l}\text { Ectopia lentis, exotropia, or severe } \\
\text { myopia }\end{array}$ & $\begin{array}{l}\text { Congenital binocular ectopia lentis, } \\
\text { impaired vision }\end{array}$ & $\begin{array}{l}\text { Congenital binocular ectopia lentis, exotropia, impaired } \\
\text { vision }\end{array}$ \\
\hline Skeleton & $\begin{array}{l}\text { Dolichostenomelia and } \\
\text { arachnodactyly, osteoporosis and } \\
\text { higher risk of fractures, bone } \\
\text { deformities }\end{array}$ & Long fingers, kyphoscoliosis & $\begin{array}{l}\text { Long fingers, the physiologic curvature of thoracic vertebra } \\
\text { straightened, narrowed joint space of bilateral wrist, } \\
\text { osteoporosis, decreased BMD (values -3.3) }\end{array}$ \\
\hline $\begin{array}{l}\text { Skin (not } \\
\text { common) }\end{array}$ & $\begin{array}{l}\text { Light skin and brittle red to blond hair, } \\
\text { malar flush }\end{array}$ & Not found & $\begin{array}{l}\text { Hyperpigmentation, especially in the interphalangeal } \\
\text { joints, histopathologic study revealed hyperpigmentation, } \\
\text { hyperkeratosis, verrucous hyperplasia in the basal layer } \\
\text { of the epidermis }\end{array}$ \\
\hline CNS & $\begin{array}{l}\text { Intellectual disability, psychiatric and } \\
\text { behavioral problems, seizures, and } \\
\text { extrapyramidal sign }\end{array}$ & $\begin{array}{l}\text { Psychological and behavioral } \\
\text { abnormalities, irascibility, intellectual } \\
\text { disability, ataxia, unstable gait }\end{array}$ & $\begin{array}{l}\text { Intellectual disability, scored } 70 \text { on WISC-IV, } 25 \text { of } 30 \text { on } \\
\text { MMSE, } 17 \text { of } 30 \text { on MoCA, psychological and behavioral } \\
\text { abnormalities, low self-learning ability }\end{array}$ \\
\hline $\begin{array}{l}\text { Vascular } \\
\text { system }\end{array}$ & Venous or arterial thromboembolism & Not found & Cerebral venous sinus thrombosis \\
\hline Others & $\begin{array}{l}\text { Congenital defects including } \\
\text { congenital heart defect and neural } \\
\text { tube defect }\end{array}$ & Not found & $\begin{array}{l}\text { EMG, ECG, cardiac color ultrasound, peripheral artery and } \\
\text { peripheral venous examinations all normal }\end{array}$ \\
\hline
\end{tabular}

Abbreviations: BMD = bone mineral density (value below -2.5 means higher risk of fractures); MMSE = Mini-Mental State Examination; MoCA = Montreal Cognitive Assessment; WISC-IV = Wechsler Intelligence Scale for Children, 4th edition. 
In this case, the patient had CVST and multisystem dysfunction due to HHcy (table 2), including ocular anomalies, skeletal system deformities (figure 1, D), skin diseases (figure $1, \mathrm{E}$ and $\mathrm{F}$ ), and CNS abnormalities.
Questions for consideration:

1. What are the common causes of HHcy?

2. How can we confirm the root cause of HHcy in our patient?

GO TO SECTION 3 


\section{Section 3}

The common causes for HHcy can be divided into exogenous factors such as overintake of cysteine (Cys) or methionine (Met) or dietary deficiencies of vitamins $\mathrm{B}_{6}, \mathrm{~B}_{12}$, or folate $^{6}$ (figure 2). Exogenous factors of HHcy were considered unlikely-there was no history of dietary restrictions or overuse of vitamins. However, the patient's older sister (II-1 in the pedigree of figure 1G) also had multiple medical problems (table 2). Thus, the patient's HHcy may have been due to inherited factors, which tend to be a considerable cause of HHcy.

For our patient, we first screened for common genetic defects and biochemical abnormalities. Investigations revealed elevated plasma Met $(437.77 \mu \mathrm{mol} / \mathrm{L})$ without a normal level of methylmalonic acid on plasma aminoacid chromatomatography. These results were consistent with cystathionine $\beta$-synthase (CBS) and methylenetetrahydrofolate reductase (MTHFR) deficiency ${ }^{6}$ (table 3 ).

To confirm the diagnosis, ${ }^{7}$ an experimental study was conducted using all exons of CBS and MTHFR genes in the pedigree (figure 1, G). We found novel compound heterozygous mutations of the CBS gene, c.551T $>C$ (p.leucine 184 proline) and c.949A $>\mathrm{G}$ (p.arginine 317 glycine) (figure $1, \mathrm{H}$ ), which were coseparated and predicted as damaged and possibly damaged according to SIFT (sift. jcvi.org/) and PolyPhen (genetics.bwh.harvard.edu/pph2/ ). Interestingly, the 2 novel mutations occurred at highly conserved positions across different species (figure 1, I). To our knowledge, this is the first time this has been reported in the literature, including from the National Heart Blood and Lung Institute Exome Sequencing Project, 1000 Genomes Project, or the Single Nucleotide Polymorphism Database, and 50 healthy controls from

Figure 2 The biochemical metabolism of homocysteine (Hcy)

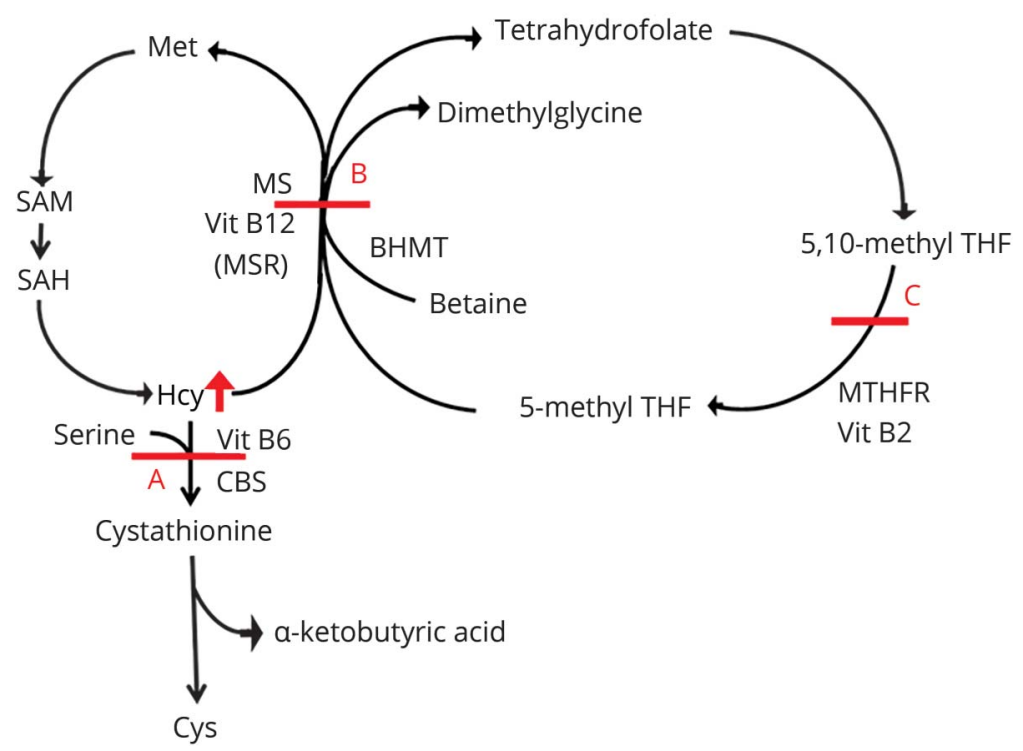

(A) Hcy and serine can transfer to cystathionine, and the reactions are catalyzed by vitamin $\mathrm{B}_{6}$ and cystathionine $\beta$-synthase (CBS) resynthesis. (B) Remethylation to methionine of Hcy pathways. Vitamin $B_{12}$, betaine, and betaine homocysteine methyltransferase (BHMT) are independent. (C) In the cycle of methylenetetrahydrofolate (THF), vitamin $B_{2}$ and methylenetetrahydrofolate reductase (MTHFR) are indispensable. Cys = cysteine; Met = methionine; MS = methionine synthase; MSR = methionine synthase reductase; SAM = S-adenosyl methionine; $\mathrm{SAH}=$ S-adenosyl homocysteine.

Table 3 Different genes/proteins deficiency causing different variations of organic acids

\begin{tabular}{|c|c|c|c|c|}
\hline Genes deficiency & Protein & $\begin{array}{l}\text { Hcy (normal } \\
15 \mu \mathrm{mol} / \mathrm{L} \text { ) }\end{array}$ & $\begin{array}{l}\text { Met (normal } \\
50 \mu \mathrm{mol} / \mathrm{L})\end{array}$ & $\begin{array}{l}\text { MMA (normal } \\
<4 \mu \mathrm{mol} / \mathrm{L} \text { ) }\end{array}$ \\
\hline Methionine synthase & MS & $\uparrow$ & $\downarrow$ & - \\
\hline Methionine synthase reductase & MSR & $\uparrow$ & $\downarrow$ & - \\
\hline Cystathionine $\beta$-synthase & CBS & $\uparrow$ & $\uparrow$ & - \\
\hline Methylenetetrahydrofolate reductase & MTHFR & $\uparrow$ & $\uparrow$ & - \\
\hline $\begin{array}{l}\text { Genes deficiency associated with cobalamin } \\
\left.\text { (MMACHC, }{ }^{1} \text { MMADHC, }{ }^{2} A B C D 4^{3}{ }^{3} C F C 1^{4}\right)\end{array}$ & Protein associated with cobalamin & $\uparrow$ & - & $\uparrow$ \\
\hline
\end{tabular}

Abbreviations: $A B C D 4=$ ATP-binding cassette-D4; $H C F C 1$ = host cell factor $\mathrm{c}-1 ;$ MMACHC = methylmalonic acid homocystinuria type $\mathrm{C}$ protein; $M M A D H C=$ methylmalonic acid homocystinuria type $D$ protein. 
China origin (supplemental information, doi.org/10.5061/ dryad.6cc5h8f).

Whole-exome sequencing bioinformatics was performed and confirmed that there were no other potential associated genes mutation in this pedigree. Therefore, these results indicate that the compound heterozygous mutations of CBS gene,
c.551T $>$ C and c.949A $>$ G, which have not been previously reported, had a strong relationship with homocystinuria in this pedigree.

\section{Question for consideration:}

1. What is the next step in management? How should one treat the CVST? How should one treat the HHcy? 


\section{Section 4}

For CVST, low-molecular-weight heparin was given to the patient followed by oral anticoagulants. ${ }^{2}$ For HHcy, the current treatment strategies primarily focus on correcting the biochemical abnormalities with supplementation of vitamin $\mathrm{B}_{6}(100-200 \mathrm{mg} / \mathrm{d})$, folate $(5 \mathrm{mg} / \mathrm{d})$, and vitamin $\mathrm{B}_{12}(5 \mathrm{mg} /$ d), along with a Met and Cys restricted diet. ${ }^{8}$ Betaine is another possible treatment for these patients as it provides an alternate remethylation pathway to convert excess Hcy to Met (figure 2), especially in patients who could not achieve target levels of Hcy by other means. ${ }^{8}$

One month later, the CTV image showed that the previously obstructed sinuses were unobstructed but narrowed (figure 1,C). Three months later, the patient attended school, as her learning ability and behavior had improved. After a year, the patient had no further thrombotic events and a normal tHcy. In addition, the patient was counseled about birth control and avoiding estrogencontaining contraceptives, which may increase risk of thrombosis including CVST. ${ }^{1}$ If the patient were to have a future pregnancy, prophylactic anticoagulation with low-molecular-weight heparin would be recommended postpartum and during the third trimester to reduce the risk of thromboembolism. ${ }^{8}$

\section{Discussion}

We report a case of CVST due to homocystinuria. Homocystinuria due to CBS deficiency (OMIM \#236200) is a rare disorder of sulfur amino acid metabolism, with elevated plasma concentrations of tHcy and Met and increased excretion of Hcy in urine. 9 So far, at least 164 mutations in CBS have been reported (cbs.lf1.cuni.cz/index.php). In our case, novel compound heterozygous pathogenic mutations of CBS, c.551T $>\mathrm{C}$ and c.949A $>\mathrm{G}$, led to HHcy causing CVST and multiple system dysfunction, skin hyperpigmentation, and straightened vertebra.

The case expands the phenotypes and mutation spectrum of CBS resulting in homocystinuria. This discovery is helpful in presymptomatic molecular diagnosis, prenatal diagnosis, management of patients with homocystinuria, and genetic counseling of families. The treatment management and corresponding prognosis indicate that early diagnosis, early prevention, and early treatment are beneficial to prognosis. Gene detection technique is of great value to diagnose disease and to find the new gene mutation in clinical genopathy and it should be widely used in clinical practice.
This case also highlights that (1) for CVST in young patients without common risk factors, HHcy is a possible cause; and (2) for patients with HHcy, once exogenous factors of HHcy are ruled out, genetic testing should be done, especially if there is evidence of multiorgan dysfunction or a strong family history.

\section{Author contributions}

Lijun Xiao: study design, acquisition of clinical data, analysis of data, drafting the manuscript. Wenping Gu: study concept and design, analysis of data, revising the manuscript. Bin Jiao: statistical analysis, drafting the manuscript. Yunhai Liu: acquisition of clinical data, study supervision. Xiaosu Yang: study concept and design, analysis of data.

\section{Acknowledgment}

JiFeng Guo, MD, PhD (Xiangya Hospital) provided general advice or guidance and reviewed the manuscript. Jun Yin, $\mathrm{MD}$, $\mathrm{PhD}$ (Xiangya Hospital) and Long Luo, MD (Xiangya Hospital) offered technical help. Rui Yang, MD, PhD (Xiangya Hospital) reviewed the manuscript.

\section{Study funding}

No targeted funding reported.

\section{Disclosure}

L. Xiao, W. Gu, and B. Jiao report no disclosures relevant to the manuscript. Y. Liu received funding from China Ministries of Health. X. Yang received honoraria from the Department of Science and Technology of Hunan province. Go to Neurology.org/ $\mathrm{N}$ for full disclosures.

\section{References}

1. Behrouzi R, Punter M. Diagnosis and management of cerebral venous thrombosis. Clin Med2018;18:75-79.

2. Saposnik G, Barinagarrementeria F, Brown RD, et al. Diagnosis and management of cerebral venous thrombosis. Stroke 2011;42:1158-1192.

3. Kumar A, Palfrey HA, Pathak R, et al. The metabolism and significance of homocysteine in nutrition and health. Nutr Metab 2017;14:78.

4. Lauw MN, Barco S, Coutinho JM, et al. Cerebral venous thrombosis and thrombophilia: a systematic review and meta-analysis. Semin Thromb Hemost 2013;39: 913-927.

5. Karaca M, Hismi B, Ozgul RK, et al. High prevalence of cerebral venous sinus thrombosis (CVST) as presentation of cystathionine beta-synthase deficiency in childhood: molecular and clinical findings of Turkish probands. Gene 2014;534: 197-203.

6. Nazki FH, Sameer AS, Ganaie BA. Folate: metabolism, genes, polymorphisms and the associated diseases. Gene 2014;533:11-20.

7. Jiao B, Guo J, Wang Y, et al. C9orf72 mutation is rare in Alzheimer's disease, Parkinson's disease, and essential tremor in China. Front Cell Neurosci 2013;7:164.

8. Kumar T, Sharma GS, Singh LR. Homocystinuria: therapeutic approach. Clinica Chim Acta 2016;458:55-62.

9. Brenton DP, Dow CJ, James JI, et al. Homocystinuria and Marfan's syndrome: a comparison. J Bone Joint Surg Br 1972;54:277-298. 


\section{Neurology}

Clinical Reasoning: A 14-year-old girl with headache, seizures, and confusion Lijun Xiao, Wenping Gu, Bin Jiao, et al.

Neurology 2019;92; $161-\mathrm{e} 167$

DOI 10.1212/WNL.0000000000006726

This information is current as of January 7, 2019

Updated Information \&
Services

References

Subspecialty Collections

Permissions \& Licensing

Reprints including high resolution figures, can be found at: http://n.neurology.org/content/92/2/e161.full

This article cites 9 articles, 2 of which you can access for free at: http://n.neurology.org/content/92/2/e161.full\#ref-list-1

This article, along with others on similar topics, appears in the following collection(s):

Cerebral venous thrombosis

http://n.neurology.org/cgi/collection/cerebral_venous_thrombosis Metabolic disease (inherited)

http://n.neurology.org/cgi/collection/metabolic_disease_inherited Organic acid

http://n.neurology.org/cgi/collection/organic_acid

Information about reproducing this article in parts (figures,tables) or in its entirety can be found online at:

http://www.neurology.org/about/about_the_journal\#permissions

Information about ordering reprints can be found online:

http://n.neurology.org/subscribers/advertise

Neurology ${ }^{\circledR}$ is the official journal of the American Academy of Neurology. Published continuously since 1951, it is now a weekly with 48 issues per year. Copyright @ 2019 American Academy of Neurology. All rights reserved. Print ISSN: 0028-3878. Online ISSN: 1526-632X.

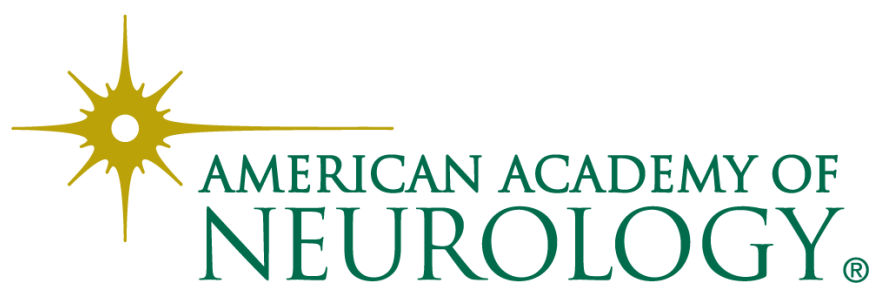

